\title{
GMR
}

\section{Statistical analysis of the relationship between IL-10 gene promoter polymorphisms and the development of coronary artery disease}

\author{
L. Wu, M.H. Zhao, G.Y. Geng, L. Mao and H.J. Liu \\ Department of Cardiology, Zhengzhou People's Hospital, Zhengzhou, Henan, \\ China \\ Corresponding author: W. Lei \\ E-mail: wleilei55@126.com / liuhongjja@163.com
}

Genet. Mol. Res. 15 (4): gmr15047823

Received October 14, 2015

Accepted January 18, 2016

Published October 17, 2016

DOI http://dx.doi.org/10.4238/gmr15047823

Copyright (C) 2016 The Authors. This is an open-access article distributed under the terms of the Creative Commons Attribution ShareAlike (CC BY-SA) 4.0 License.

\begin{abstract}
Here, we conducted a case-control study to investigate the association between $I L-10$ gene polymorphisms and development of CAD in a Chinese population. A total of 220 patients with CAD and 236 control subjects who visited the Zhengzhou People's Hospital between May 2012 and June 2014 were selected for this study. The $I L-10-1082 \mathrm{~A} / \mathrm{G}$ and $-592 \mathrm{~A} / \mathrm{C}$ polymorphisms were genotyped by polymerase chain reaction coupled with restriction fragment length polymorphism. The chi-squared test revealed a significant difference in the distributions of the $I L-10-1082 \mathrm{~A} / \mathrm{G}$ genotypes $\left(\chi^{2}=6.32, \mathrm{P}=0.04\right)$. This data was then statistically analyzed by logistic regression analysis; we observed revealed that the CC genotype of $I L-10-1082 \mathrm{~A} / \mathrm{G}$ had a higher risk of $\mathrm{CAD}$ in comparison to the AA genotype $(\mathrm{OR}=2.09$, $95 \% \mathrm{CI}=1.11-3.97)$. Moreover, the $\mathrm{C}$ allele of $I L-10-1082 \mathrm{~A} / \mathrm{G}$ had a 1.39 fold risk of $\mathrm{CAD}$ when compared with $(\mathrm{OR}=1.39,95 \% \mathrm{CI}=1.06-$ 1.82 ). We did not observe any significant correlations between the $I L$ -
\end{abstract}

Genetics and Molecular Research 15 (4): gmr15047823 
10-592A/C genetic variation and susceptibility to CAD. In conclusion, our study suggests that the $I L-10-1082 \mathrm{~A} / \mathrm{G}$ genetic variation could influence the development of CAD in a Chinese population.

Key words: $I L-10 ;-1082 \mathrm{~A} / \mathrm{G} ;-592 \mathrm{~A} / \mathrm{C}$; Polymorphism; CAD

\section{INTRODUCTION}

Coronary artery disease is a serious disease with a high morbidity and mortality rate worldwide, as well as in China (He et al., 2005; Go et al., 2014). It is estimated that the mortality of CAD was 86.34 per $10^{5}$ in urban area and 69.24 per $10^{5}$ in rural area in 2010 , and the mortality was higher in males than that in females (Wang et al., 2014). In recent decades, morbidity and mortality related to this disease have greatly increased (Wang et al., 2014). The development of CAD is involved in multiple lifestyle and environment-related factors and their interactions, such as high age, males, high dietary sugar, alcohol use, tobacco smoking, hypertension, diabetes, obesity, low high-density lipoprotein, as well as family history of CAD (Go et al., 2013). Additionally, genetic factors play an important role in increased risk of CAD development, and previous studies have indicated that many genes are correlated with this cancer, such as vitamin D receptor gene, interleukin-17 (IL-17), IL-6, apolipoprotein A5 (APOA5), cyclooxygenase-2 (COX-2), matrix metalloproteinase-2 (MMP-2) and 7-Alpha cholesterol hydroxylase (CYP7A1) (Abu et al., 2015; Geng et al., 2015; Iwanicki et al., 2015; Li et al., 2015; Shi et al., 2015b; Xia et al., 2015; Zhang et al., 2015).

Inflammation plays an important role in CAD pathogenesis, such as $I L-6, I L-1 \beta, I L$ 8 , and $I L-17$ genetic polymorphisms are associated with susceptibility to CAD (Geng et al., 2015; Li et al., 2015; Yang et al., 2015). IL-10 is a member of the immunoregulatory cytokine family, and is located on chromosome 1q31-1q32. Many published studies have indicated that polymorphisms in the IL-10 gene are correlated with pathogenesis of CAD in different populations; however, the results remain conflicting (Blagodatskikh et al., 2010; Koch et al., 2001; Guo et al., 2012; Liu et al., 2013; Elsaid et al., 2014; Ren and She, 2015).Here, we carried out a study to assess the role of two common polymorphic sites in $I L-10$ gene (-1082A/ $\mathrm{G}$ and $-592 \mathrm{~A} / \mathrm{C}$ ) in the $\mathrm{CAD}$ risk.

\section{MATERIAL AND METHODS}

\section{Study subjects}

The current study comprised of 246 patients diagnosed with CAD who visited the Zhengzhou People's Hospital between May 2012 and June 2014 were enrolled for this study. CAD was confirmed in all patients using coronary angiography examination. CAD was confirmed in those patients with $>70 \%$ coronary artery stenosis, and those exhibiting typical angina symptoms without any aortic valvular disease and with a history of previous or acute myocardial infarction. Patients who had a history of malignant tumors, serious liver and kidney diseases or acute or chronic diseases were excluded from our study. The mean age of CAD patients was $61.43 \pm 9.63$ years, and there were 97 (39.43\%) females and 149 (60.57\%) males in CAD patients.

Two hundred and fifty-nine control subjects were randomly collected from among individuals who visited outpatient department at the Zhengzhou People's Hospital during

Genetics and Molecular Research 15 (4): gmr15047823 
the same time period. Control subjects who had a history of atherosclerotic lesions, CAD, malignant tumors, end-stage liver and kidney diseases or acute or chronic diseases were excluded from the control groups. The mean age of control subjects was $59.67 \pm 8.41$ years. This study comprised of 118 (45.56\%) female and 141 (54.44\%) male controls.

The demographic lifestyle characteristics of patients with CAD and control subjects, including mean age, gender, tobacco smoking, alcohol consumption, body mass index (BMI), hypertension and type 2 diabetes mellitus, were collected from structured questionnaires investigated by face-to-face interviews. In addition, the clinical characteristics, including total cholesterol (TC), low-density lipoprotein cholesterol (LDL-c), high-density lipoprotein cholesterol (HDL-c) and triglyceride, were collected from medical records. The performance of our study was approved by the Institutional Review Board of Zhengzhou People's Hospital. Written informed consent from all study subjects was obtained prior to enrollment.

\section{Genetic analysis}

Five $\mathrm{mL}$ peripheral blood was obtained from each study subject, and the blood samples were stored at $-20^{\circ} \mathrm{C}$ in refrigerator until using. DNA was extracted from peripheral blood using the TIANamp Blood DNA Kit (Tiangen, Beijing, China). Genotyping of the $I L-10-1082 \mathrm{~A} /$ $\mathrm{G}$ and $-592 \mathrm{~A} / \mathrm{C}$ polymorphisms were analyzed using polymerase chain reaction-restriction fragment length polymorphism (PCR-RFLP). The primers, restriction enzymes and digested fragments of $I L-10-1082 \mathrm{~A} / \mathrm{G}$ and $-592 \mathrm{~A} / \mathrm{C}$ polymorphisms are summarized in Table 1 . The PCR reaction cycles were set according to the following program: an initial denaturation at $95^{\circ} \mathrm{C}$ for 15 minutes, followed by 35 cycles of denaturation at $94^{\circ} \mathrm{C}$ for 30 seconds, annealing at $59^{\circ} \mathrm{C}$ for 45 seconds, $72^{\circ} \mathrm{C}$ for 60 seconds, and a finally extension at $72^{\circ} \mathrm{C}$ for 10 minutes. The amplification product was at the position of $412 \mathrm{bp}$ for $I L-10-1082 \mathrm{~A} / \mathrm{G}$, and was at the position of $136 \mathrm{bp}$ for $I L-10-1082 \mathrm{~A} / \mathrm{G}$.

\begin{tabular}{|c|c|c|c|}
\hline Gene polymorphism & Primers & Restriction enzyme & Digested fragment \\
\hline$-1082 \mathrm{~A} / \mathrm{G}$ & $\begin{array}{l}\text { 5'-CTCGCCGCAACCAACTGGC -3' } \\
\text { 5'-TCTTACCTATCCCTACTTCC -3' }\end{array}$ & Mnll & AA: 136 bp; AG: 136, 103 and 33bp; GG: 103 and 33bp \\
\hline$\overline{-592 \mathrm{~A} / \mathrm{C}}$ & $\begin{array}{l}\text { 5'-GGTGAGCACTACCTGACTAGC-3' } \\
\text { 5'-CTGGCTGCAACCCAACTGGC-3' }\end{array}$ & $R s a \mathrm{I}$ & AA: 236 and $176 \mathrm{bp} ; \mathrm{AC}: 412,236$ and $176 \mathrm{bp} ; \mathrm{CC}: 412 \mathrm{bp}$ \\
\hline
\end{tabular}

\section{Statistical analysis}

The chi-square test was performed to assess any probable deviations of the $I L-10$ $-1082 \mathrm{~A} / \mathrm{G}$ and $-592 \mathrm{~A} / \mathrm{C}$ genotype distributions in the CAD patients and controls from the Hardy-Weinberg equilibrium (HWE). Multiple logistic regression analyses were performed to evaluate the relationship between the $I L-10-1082 \mathrm{~A} / \mathrm{G}$ and $-592 \mathrm{~A} / \mathrm{C}$ gene polymorphisms and development of, as well as susceptibility to, CAD. Odds ratio (OR) along with $95 \%$ confidence intervals (CIs) with adjustment for possible confounders were used to estimate the results. All analyses were carried out using SPSS 16.0 (SPSS Inc., Chicago, IL, USA). P values $<0.05$ were regarded as statistically significant. 


\section{RESULTS}

Compared with the control subjects, the chi-square test or $t$-test revealed that CAD patients were more likely to have higher age $\left(\chi^{2}=2.19, \mathrm{P}=0.015\right)$, higher $\mathrm{BMI}\left(\chi^{2}=12.06, \mathrm{P}\right.$ $<0.001)$, higher TC level $(\mathrm{t}=3.31, \mathrm{P}=0.001)$, higher TG level $(\mathrm{t}=5.48, \mathrm{P}<0.001)$ and lower HDL-c level $(\mathrm{t}=6.13, \mathrm{P}<0.001)$, have a habit of tobacco smoking $\left(\chi^{2}=8.04, \mathrm{P}=0.01\right)$, and suffer from hypertension $\left(\chi^{2}=24.16, \mathrm{P}<0.001\right)$ and type 2 diabetes $\left(\chi^{2}=9.50, \mathrm{P}<0.001\right)$ (Table 2). Moreover, there were no significant differences between CAD patients and control subjects in terms of gender $(\mathrm{t}=2.19, \mathrm{P}=0.015)$, alcohol consumption $\left(\chi^{2}=1.61, \mathrm{P}=0.21\right)$ and LDL-c level $(\mathrm{t}=0.27, \mathrm{P}=0.39)$.

Table 2. Characteristics of coronary artery disease (CAD) patients and control subjects.

\begin{tabular}{|c|c|c|c|c|c|c|}
\hline Characteristics & CAD patients $(\mathrm{N}=246)$ & $\%$ & Controls $(\mathrm{N}=259)$ & $\%$ & $\chi^{2}$-test or $t$ test & P value \\
\hline Mean age, years & $61.43 \pm 9.63$ & & $59.67 \pm 8.41$ & & 2.19 & 0.015 \\
\hline \multicolumn{7}{|l|}{ Gender } \\
\hline Female & 97 & 39.43 & 118 & 45.56 & & \\
\hline Male & 149 & 60.57 & 141 & 54.44 & 1.94 & 0.16 \\
\hline \multicolumn{7}{|l|}{ Tobacco smoking } \\
\hline No & 131 & 53.25 & 170 & 65.64 & & \\
\hline Yes & 115 & 46.75 & 89 & 34.36 & 8.04 & 0.01 \\
\hline \multicolumn{7}{|l|}{ Alcohol consumption } \\
\hline No & 151 & 61.38 & 173 & 66.80 & & \\
\hline$\overline{\text { Yes }}$ & 95 & 38.62 & 86 & 33.20 & 1.61 & 0.21 \\
\hline BMI, $\mathrm{kg} / \mathrm{m}^{2}$ & $26.65 \pm 2.45$ & & $24.17 \pm 2.17$ & & 12.06 & $<0.001$ \\
\hline \multicolumn{7}{|l|}{ Hypertension } \\
\hline No & 117 & 47.56 & 179 & 69.11 & & \\
\hline Yes & 129 & 52.44 & 80 & 30.89 & 24.16 & $<0.001$ \\
\hline \multicolumn{7}{|l|}{ Type 2 diabetes } \\
\hline No & 190 & 77.24 & 227 & 87.64 & & \\
\hline Yes & 56 & 22.76 & 32 & 12.36 & 9.50 & 0.002 \\
\hline Total cholesterol, $\mathrm{mM}$ & $4.13 \pm 1.03$ & & $3.82 \pm 1.07$ & & 3.31 & 0.001 \\
\hline Low-density lipoprotein cholesterol, mM & $2.49 \pm 1.52$ & & $2.46 \pm 0.92$ & & 0.27 & 0.39 \\
\hline High-density lipoprotein cholesterol, mM & $1.12 \pm 0.53$ & & $1.38 \pm 0.42$ & & 6.13 & $<0.001$ \\
\hline Triglyceride, $\mathrm{mM}$ & $1.78 \pm 0.87$ & & $1.36 \pm 0.85$ & & 5.48 & $<0.001$ \\
\hline
\end{tabular}

Genotype distributions of $I L-10-1082 \mathrm{~A} / \mathrm{G}$ and $-592 \mathrm{~A} / \mathrm{C}$ genetic variations are described in Table 3. The genotype distributions of $I L-10-1082 \mathrm{~A} / \mathrm{G}$ in the CAD patients, as well as the controls, were in agreement with the Hardy-Weinberg equilibrium ( $\mathrm{P}$ values for HWE in patients and controls were 0.66 and 0.65 , respectively), whereas the genotype distributions of $I L-10-592 \mathrm{~A} / \mathrm{C}$ were not (P values for HWE in patients and controls were both less than 0.05). The chi-squared test revealed a significant difference in the distributions of the $I L-10-1082 \mathrm{~A} / \mathrm{G}$ genotypes $\left(\chi^{2}=6.32, \mathrm{P}=0.04\right)$, while the results did not show significant difference in genotype distributions of $I L-10-592 \mathrm{~A} / \mathrm{C}\left(\chi^{2}=3.27, \mathrm{P}=0.19\right)$.

The relationship between $I L-10-1082 \mathrm{~A} / \mathrm{G}$ and $-592 \mathrm{~A} / \mathrm{C}$ gene polymorphisms are summarized in Table 4. The results of unconditional multiple logistic regression analysis revealed that the $\mathrm{CC}$ genotype of $I L-10-1082 \mathrm{~A} / \mathrm{G}$ had a higher risk of CAD in comparison to the AA genotype $(\mathrm{OR}=2.09,95 \% \mathrm{CI}=1.11-3.97)$. Moreover, the $\mathrm{C}$ allele of $I L-10-1082 \mathrm{~A} / \mathrm{G}$ had a 1.39 fold risk of $\mathrm{CAD}$ when compared with $(\mathrm{OR}=1.39,95 \% \mathrm{CI}=1.06-1.82)$. However, we did not observe any significant correlations between the $I L-10-592 \mathrm{~A} / \mathrm{C}$ genetic variation and susceptibility to CAD. 
Table 3. Genotype distributions of $I L-10-1082 \mathrm{~A} / \mathrm{G}$ and $-592 \mathrm{~A} / \mathrm{C}$ gene polymorphisms between patients with coronary artery disease (CAD) and control subjects.

\begin{tabular}{|c|c|c|c|c|c|c|c|c|}
\hline \multirow[t]{2}{*}{ IL-10 } & \multirow[t]{2}{*}{ Patients $(\mathrm{N}=246)$} & \multirow[t]{2}{*}{$\%$} & \multirow[t]{2}{*}{ Controls $(\mathrm{N}=259)$} & \multirow[t]{2}{*}{$\%$} & \multicolumn{2}{|c|}{ P for HWE } & \multirow[t]{2}{*}{$\chi^{2}$ test } & \multirow[t]{2}{*}{$P$ value } \\
\hline & & & & & Cases & Controls & & \\
\hline \multicolumn{9}{|c|}{$-1082 \mathrm{~A} / \mathrm{G}$} \\
\hline AA & 98 & 39.84 & 125 & 48.26 & & & & \\
\hline $\mathrm{AC}$ & 112 & 45.53 & 112 & 43.24 & & & & \\
\hline $\mathrm{CC}$ & 36 & 14.63 & 22 & 8.49 & 0.66 & 0.65 & 6.32 & 0.04 \\
\hline \multicolumn{9}{|c|}{$-592 \mathrm{~A} / \mathrm{C}$} \\
\hline $\mathrm{AA}$ & 117 & 47.56 & 111 & 42.86 & & & & \\
\hline AG & 116 & 47.15 & 140 & 54.05 & & & & \\
\hline GG & 13 & 5.28 & 8 & 3.09 & 0.02 & $<0.001$ & 3.27 & 0.19 \\
\hline
\end{tabular}

HWE: Hardy-Weinberg equilibrium.

Table 4. Relationship between $I L-10-1082 \mathrm{~A} / \mathrm{G}$ and $-592 \mathrm{~A} / \mathrm{C}$ gene polymorphisms and coronary artery disease.

\begin{tabular}{|c|c|c|c|c|c|c|}
\hline IL-10 & Patients $(\mathrm{N}=246)$ & $\%$ & Controls $(\mathrm{N}=259)$ & $\%$ & OR $(95 \% \mathrm{CI})^{1}$ & P value \\
\hline \multicolumn{7}{|c|}{$-1082 \mathrm{~A} / \mathrm{G}$} \\
\hline$\overline{\mathrm{AA}}$ & 98 & 39.84 & 125 & 48.26 & 1.0 (Reference) & - \\
\hline $\mathrm{AC}$ & 112 & 45.53 & 112 & 43.24 & $1.64(0.87-3.11)$ & 0.10 \\
\hline $\mathrm{CC}$ & 36 & 14.63 & 22 & 8.49 & $2.09(1.11-3.97)$ & 0.01 \\
\hline \multicolumn{7}{|c|}{ Allele } \\
\hline $\mathrm{A}$ & 308 & 62.60 & 362 & 69.88 & 1.0 (Reference) & - \\
\hline $\mathrm{C}$ & 184 & 37.40 & 156 & 30.12 & $1.39(1.06-1.82)$ & 0.01 \\
\hline \multicolumn{7}{|c|}{$-592 \mathrm{~A} / \mathrm{C}$} \\
\hline $\mathrm{AA}$ & 117 & 47.56 & 111 & 42.86 & 1.0 (Reference) & - \\
\hline$\overline{\mathrm{AG}}$ & 116 & 47.15 & 140 & 54.05 & $0.79(0.54-1.14)$ & 0.19 \\
\hline GG & 13 & 5.28 & 8 & 3.09 & $1.54(0.57-4.46)$ & 0.35 \\
\hline \multicolumn{7}{|c|}{ Allele } \\
\hline A & 350 & 71.14 & 362 & 69.88 & 1.0 (Reference) & - \\
\hline $\bar{G}$ & 142 & 28.86 & 156 & 30.12 & $0.94(0.71-1.25)$ & 0.66 \\
\hline
\end{tabular}

${ }^{1}$ Adjusted for gender, age, tobacco smoking, BMI, hypertension, type 2 diabetes, total cholesterol, high-density lipoprotein cholesterol and triglyceride. $\mathrm{OR}=$ odds ratio; $\mathrm{CI}=$ confidence interval.

Moreover, interaction analysis was carried out to identify the relationship between $I L-10-1082 \mathrm{~A} / \mathrm{G}$ and $-592 \mathrm{~A} / \mathrm{C}$ gene polymorphisms and demographic, lifestyle and clinical characteristics in the risk of CAD. However, no interaction was observed between them.

\section{DISCUSSION}

Here, we attempted to estimate the relationship between the $I L-10-1082 \mathrm{~A} / \mathrm{G}$ and $-592 \mathrm{~A} / \mathrm{C}$ genetic polymorphisms and CAD risk; we discovered a correlation between the CC genotype and $\mathrm{C}$ allele of $I L-10-1082 \mathrm{~A} / \mathrm{G}$ and increased CAD risk in the Chinese population. Moreover, the $I L-10-592 \mathrm{~A} / \mathrm{C}$ polymorphism had no association with development of CAD.

IL-10 belongs to the family of chemokines, and it locates on chromosome 1q31-q32, and $-1082 \mathrm{~A} / \mathrm{G}$ and $-592 \mathrm{~A} / \mathrm{C}$ are located at the promoter regions. Polymorphisms in the $I L-10$ can alter the structure and quantity of this gene, and consequently influencing the expression and function of the product. Previous studies have demonstrated that $I L-10$ genetic polymorphisms could affect the risk of many autoimmune diseases, such as rheumatoid arthritis, systemic lupus erythematosus, Graves' disease and peptic ulcer (Sugimoto et al., 2007; Liu et al., 2011; da Silva et al., 2004; Lagha et al., 2015). Sugimoto et al. (2007) carried out a study in a Japanese population, and reported that $I L-10-1082 /-819 /-592$ haplotypes were correlated

Genetics and Molecular Research 15 (4): gmr15047823 
with an elevated risk for gastric cancer. Liu et al. (2011) investigate the role of the $I L-10$ genotype polymorphism in susceptibility to Graves' disease, and demonstrated that $I L-10$ -1082 genetic polymorphism was significantly correlated with Graves' disease susceptibility in the Chinese population. da Silva et al. (2014) carried out a study in a Brazilian population, and reported that the $I L-10-1082$ genetic polymorphism may influence the systemic lupus erythematosus susceptibility. Lagha et al. (2015) conducted a study in a Tunisian population with 104 rheumatoid arthritis and 150 healthy controls, and reported that genetic variation in $I L-10-1082 \mathrm{~A} / \mathrm{G}$ was associated with rheumatoid arthritis risk.

In regards to the role of $I L-10-1082 \mathrm{~A} / \mathrm{G}$ and $-592 \mathrm{~A} / \mathrm{C}$ polymorphisms in CAD risk, several previous studies have reported conflicting results (Koch et al., 2001; Blagodatskikh et al., 2010; Elsaid et al., 2014; Ren and She, 2015; Yang et al., 2015). Blagodatskikh et al. (2010) evaluated the association of the $I L-10-1082 \mathrm{~A} / \mathrm{G}$ genetic variation with the development of CAD in a Russian population, and discovered that $I L-10-1082 \mathrm{~A} / \mathrm{G}$ genetic polymorphism could influence the risk of CAD. Elsaid et al. (2014) discovered an association between the $I L-10-1082 \mathrm{~A} / \mathrm{G}$ gene polymorphisms and an increased prevalence of CAD. Ren and She (2015) done a study in a Chinese population, and revealed that $I L-10-1082 \mathrm{~A} / \mathrm{G}$ is correlated with an increased risk of CAD. Yang et al. (2015) conducted a study in a Chinese population, and suggested that the $I L-10$ $-1082 \mathrm{~A} / \mathrm{G}$ polymorphisms might be involved in the risk of developing CAD. However, some studies reported inconsistent results. Guo et al. (2012) observed that $I L-10-1082 \mathrm{~A} /$ $\mathrm{G}$ was unlikely to be a significant biomarker to CAD susceptibility in the Han Chinese population. Koch et al. (2001) carried out a study in a German 998 patients with CAD and 340 control subjects, and did not reported an correlation of $I L-10-1082 \mathrm{~A} / \mathrm{G}$ and $-592 \mathrm{~A} / \mathrm{C}$ polymorphisms with the risk of CAD. In our study, we observed an association between the $I L-10-1082 \mathrm{~A} / \mathrm{G}$ polymorphism and the pathogenesis of CAD. Further studies with larger scale samples are required to validate our findings.

Three limitations should be considered in the present study. First, the patients and control subjects were selected from only one hospital in China, which could not represent the general population in other places of China. Second, more gene polymorphisms may be involved in the development of CAD, but we only investigate the role of $I L-10$ polymorphisms in the risk of CAD. Third, the samples of this study is relatively small, which may reduce the statistical power to find difference between groups.

In conclusion, our study suggests that the $I L-10-1082 \mathrm{~A} / \mathrm{G}$ genetic variation could influence the development of CAD in a Chinese population, and $I L-10-1082 \mathrm{~A} / \mathrm{G}$ could be a predictive biomarkers for early detection of CAD.

\section{Conflict of interest}

The authors declare no conflict of interest.

\section{ACKNOWLEDGMENTS}

We thank for the great help from nurses of Zhengzhou People's Hospital, and these staffs help us to perform face to face interview to study subjects.

Genetics and Molecular Research 15 (4): gmr15047823 


\section{REFERENCES}

Abu E, Maaty MA, Hassanein SI and Gad MZ (2015). Genetic variation in vitamin D receptor gene (Fok1:rs2228570) is associated with risk of coronary artery disease. Biomarkers 21: 1-5.

Blagodatskikh KA, Evdokimova MA, Agapkina IuV, Nikitin AG, et al. (2010). [Gene IL6 G(-174)C and gene IL10 G(1082)A polymorphisms are associated with unfavourable outcomes in patients with acute coronary syndrome]. Mol. Biol. 44: 839-846.

da Silva HD, da Silva AP, da Silva HA, Asano NM, et al. (2014). Interferon gamma and Interleukin 10 polymorphisms in Brazilian patients with systemic lupus erythematosus. Mol. Biol. Rep. 41: 2493-2500.http://dx.doi.org/10.1007/ s11033-014-3106-9

Elsaid A, Abdel-Aziz AF, Elmougy R and Elwaseef AM (2014). Association of polymorphisms G(-174)C in IL-6 gene and G(-1082)A in IL-10 gene with traditional cardiovascular risk factors in patients with coronary artery disease. Indian J. Biochem. Biophys. 51: 282-292.

Geng GY, Liu HL, Zhao YJ, Wu L, et al. (2015). Correlation between polymorphisms in the IL-17A and IL-17F genes and development of coronary artery disease. Genet. Mol. Res. 14: 11488-11494. http://dx.doi.org/10.4238/2015. September.25.15

Go AS, Mozaffarian D, Roger VL, Benjamin EJ, et al.; American Heart Association Statistics Committee and Stroke Statistics Subcommittee (2013). Heart disease and stroke statistics--2013 update: a report from the American Heart Association. Circulation 127: e6-e245.http://dx.doi.org/10.1161/CIR.0b013e31828124ad

Go AS, Mozaffarian D, Roger VL, Benjamin EJ, et al.; American Heart Association Statistics Committee and Stroke Statistics Subcommittee (2014). Heart disease and stroke statistics--2014 update: a report from the American Heart Association. Circulation 129: e28-e292.http://dx.doi.org/10.1161/01.cir.0000441139.02102.80

Guo J, He YH, Chen F, Jiang MH, et al. (2012). The A to G polymorphism at -1082 of the interleukin-10 gene is rare in the Han Chinese population. Mol. Med. Rep. 6: 894-896.

He J, Gu D, Wu X, Reynolds K, et al. (2005). Major causes of death among men and women in China. N. Engl. J. Med. 353: 1124-1134.http://dx.doi.org/10.1056/NEJMsa050467

Iwanicki T, Balcerzyk A, Niemiec P, Nowak T, et al. (2015). CYP7A1 gene polymorphism located in the $5 \notin$ upstream region modifies the risk of coronary artery disease. Dis. Markers 2015: 185969. http://dx.doi.org/10.1155/2015/185969

Koch W, Kastrati A, Böttiger C, Mehilli J, et al. (2001). Interleukin-10 and tumor necrosis factor gene polymorphisms and risk of coronary artery disease and myocardial infarction. Atherosclerosis 159: 137-144. http://dx.doi.org/10.1016/ $\underline{\text { S0021-9150(01)00467-1 }}$

Lagha A, Zidi S, Stayoussef M, Gazouani E, et al. (2015). Interleukin-1b, Interleukin1-Ra, Interleukin-10, and tumor necrosis factor-a polymorphisms in Tunisian patients with rheumatoid arthritis. Pathol. Biol. (Paris) 63: 179-184. http://dx.doi.org/10.1016/j.patbio.2015.04.004

Li L, Li E, Zhang LH, Jian LG, et al. (2015). IL-6-174G/C and IL-6-572C/G polymorphisms are associated with increased risk of coronary artery disease. Genet. Mol. Res. 14: 8451-8457.http://dx.doi.org/10.4238/2015.July.28.12

Liu N, Lu H, Tao F, Guo T, et al. (2011). An association of interleukin-10 gene polymorphisms with Graves' disease in two Chinese populations. Endocrine 40: 90-94. http://dx.doi.org/10.1007/s12020-011-9444-7

Liu W, Liu Y, Jiang H, Ding X, et al. (2013). Plasma levels of interleukin 18, interleukin 10, and matrix metalloproteinase-9 and $-137 \mathrm{G} / \mathrm{C}$ polymorphism of interleukin 18 are associated with incidence of in-stent restenosis after percutaneous coronary intervention. Inflammation 36: 1129-1135. http://dx.doi.org/10.1007/s10753-013-9647-6

Ren B and She Q (2015). Study on the association between IL-1b, IL-8 and IL-10 gene polymorphisms and risk of coronary artery disease. Int. J. Clin. Exp. Med. 8: 7937-7943.

Shi GL, Cai XX, Su YM, Chen C, et al. (2015a). Interleukin-10 promotor -592A/C polymorphism is associated with slow coronary flow in Han Chinese. Int. J. Clin. Exp. Pathol. 8: 4091-4098.

Shi Y, Zhang J, Tan C, Xu W, et al. (2015b). Matrix Metalloproteinase-2 Polymorphisms and Incident Coronary Artery Disease: A Meta-Analysis. Medicine (Baltimore) 94: e824.http://dx.doi.org/10.1097/MD.0000000000000824

Sugimoto M, Furuta T, Shirai N, Nakamura A, et al. (2007). Effects of interleukin-10 gene polymorphism on the development of gastric cancer and peptic ulcer in Japanese subjects. J. Gastroenterol. Hepatol. 22: 1443-1449. http:// dx.doi.org/10.1111/j.1440-1746.2006.04613.x

Xia J, Cai W and Peng C (2015). Association of APOA5 T1131C polymorphism and risk of coronary artery disease. Int. J. Clin. Exp. Med. 8: 8986-8994.

Yang HT, Wang SL, Yan LJ, Qian P, et al. (2015). Association of interleukin gene polymorphisms with the risk of coronary artery disease. Genet. Mol. Res. 14: 12489-12496.http://dx.doi.org/10.4238/2015.October.16.16

Wang W, Hu SS, Kong LZ, Gao RL, et al.; Editorial Board (2014). Summary of report on cardiovascular diseases in China, 2012. Biomed. Environ. Sci. 27: 552-558.

Zhang MM, Xie X, Ma YT, Zheng YY, et al. (2015). Association of COX-2 -765G $>$ C genetic polymorphism with coronary artery disease: a meta-analysis. Int. J. Clin. Exp. Med. 8: 7412-7418.

Genetics and Molecular Research 15 (4): gmr15047823 